\title{
Organizational Citizenship Behavior (OCB) and Rewards
}

\author{
Ali Alkahtani ${ }^{1}$ \\ ${ }^{1}$ Department of Human Resource Management, King Abdul Aziz University Jeddah, Saudi Arabia \\ Correspondence: Ali Alkahtani, Department of Human Resource Management, King Abdul Aziz University \\ Jeddah, Saudi Arabia. E-mail: ealkahtan@kau.edu.sa
}

Received: January 13, 2015

Accepted: February 15, 2015

Online Published: March 25, 2015

doi:10.5539/ibr.v8n4p210

URL: http://dx.doi.org/10.5539/ibr.v8n4p210

\begin{abstract}
Organizational Citizenship Behavior (OCB) has attracted the attention of academicians and practitioners due to its proven significance towards organizational effectiveness. The current study aims to estimate empirically the degree of relationship between OCB and Organizational Rewards given to employees. The study will answer the question that "Does the display of OCB have any impact on the rewards given to employees by the organization?" Five most widely acknowledged dimensions of OCB - Altruism, Courtesy, Sportsmanship, Conscientiousness, and Civic Virtue -have been considered for analysis purposes. OCB is measured through self-evaluation as well as peer evaluations to avoid any social desirability effect and common method variance errors. The organizational rewards taken in the study are Salary Increment, Promotion and Performance Appraisal Grade. The current study includes all of these together for analyzing this relationship with rigor. This is the first ever study of OCB which incorporates all five major dimensions of OCB (measured through self-reporting as well as through peer reports) and three well acknowledged types of rewards together in a single study. The study thus draws various practical implications for organizational managers on basis of the empirical findings from banking sector of Pakistan.
\end{abstract}

Keywords: organizational citizenship behaviors, organizational loyalty, organizational compliance, individual initiative, civic virtue, and self-development

\section{Introduction}

Organizational Citizenship Behaviors (OCB) is defined as "Individual behavior that is discretionary, not directly or explicitly recognized by the formal reward system and that in the aggregate promotes the effective functioning of the organization. By discretionary, we mean that the behavior is not an enforceable requirement of the role or the job description, that is, the clearly specifiable terms of the person's employment contract with the organization; the behavior is rather a matter of personal choice, such that its omission is not generally understood as punishable." (Organ, 1988, p. 4).

The research interest in OCB is increasing dramatically which is shown by the growth of number of papers published on the topic. While only 13 papers were published on this and related topics during 1983-1988, more than 122 papers have been published on these topics during 1993-1998 (Podsakoff et al., 2000).

Early researches focused primarily on OCB and its antecedents then in early 90s the research started focusing on the OCB consequences. The key issues in consequences have been (a) Managerial evaluation of performance and judgments regarding salary increment, promotion etc., and (b) Organizational performance and its effectiveness. Organ (1988) proposed "loose coupling" between employee performance and rewards i.e. employee can expect an indirect link between OCB and organizational reward.

OCB is expected to produce higher rewards because the employer may reciprocate to the employee for the benefits gained because of OCB. It enhances (i) unit and organization's efficiency, (ii) ability to attract and retain capable employees (George \& Bettenhausen, 1990), and (iii) ability to adapt to changing environment. Therefore the compensation researchers have moved their attention from older concepts of equity (Adams, 1965) to the newer and wider concept of fairness and procedural and distributive justice (Milkovich \& Newman, 1996). Hence focus o the current study is to analyze the relationship of OCB with rewards as its consequences. The rewards included in the study are Salary Increment, Promotion, and Performance Appraisal Grade.

This study is a significant contribution in the OCB literature as it was conducted in Pakistan. This is quite shocking that OCB has been extensively studied in Western cultures but only a few studies exist for other regions 
of the world. Especially, research in Eastern cultures covers China (Wanxian \& Weiwu, 2006; Farh et al., 1997; Farh et al., 2004; and Sun, 2001); Kuwait (Alotaibi, 2001); India (Moideenkutty et al., 2005); Taiwan (Huang et al., 2003); Oman (Kuehn \& Al-Busaidi, 2002) and Singapore (Van Dyne \& Ang, 1996). Investigating OCB in Pakistan was warranted as, to date, no study on OCB has been done. The cultural contexts may affect the frequency of different types of citizenship behaviors, strengths of the relationship between citizenship behaviors and consequences (Podsakoff et al., 2000). Pakistan is quite different from the developed world in legal and regulatory conditions and societal effectiveness at enforcing social norms. It is on the lower side of regulatory conditions and high on enforcing social norms. It is also different from the developed world because of religion, historical background, stage of economic development etc. Its national and organizational culture is also quite different from that of the west. Thus the current study aimed at analyzing the OCB relationship with number of rewards as its consequences in Pakistan.

Most of the OCB studies have included one or a few dimensions as Dulebohn et al. (2005) stated that they have only examined two types of OCB while other well established dimensions identified by researcher should also be examined. The future research which includes these dimensions will contribute to the literature. Thus For analyzing the OCB relationship with rewards, five extensively researched dimensions of OCB are measured in the present study.

There is lack of consensus among OCB ratings from different sources (Allen et al., 2000) implying usage of multiple raters simultaneously (Becker \& Vance, 1993; Moorman, 1991). Therefore, in addition to the self-reported OCB, peer evaluation of OCB was also taken. Two peers for each sample employee were approached independently by the researcher. Self as well as peer ratings of OCB were taken for each sample in order to avoid social desirability effect of self rating of OCB (Schnake, 1991), and "common variance error" (Gonzalez \& Garazo, 2006). Which are very common and problematic concern in OCB studies (Bell \& Menguc, 2002). Following the recommendation of Bettencourt (1998), employee OCB score was obtained by averaging the peers and employee responses also used by Van Dyne \& Ang (1996).

The current study addresses all the research concerns discussed above by conducting research on OCB in Pakistan, empirically testing OCB-Rewards relationship, taking multiple ratings of OCB and including most widely acknowledged dimensions of OCB and multiple rewards in the same study

The next section provides rationale of expecting OCB and Rewards relationship. Research design and Methodology, Analysis and Interpretations, and Conclusions are discussed in subsequent sections.

\section{Literature Review}

\subsection{OCB and Performance Evaluations}

Based on Chester Barnard's (1938) concept of the "willingness to cooperate," and Daniel Katz's (1964) distinction between 'dependable role Performance' and 'innovative and spontaneous behaviors' Organ (1988, p. 4) was the first person to differentiate discretionary behaviors from the prescribed behaviors and labeled the term as Organizational Citizenship Behaviors (OCB) After Organ coined these behaviors as Organizational citizenship Behavior, researchers worked on it and kept on identifying different dimensions of OCB. Some of these dimensions were distinct while the others were overlapping. Overall, more than 30 dimensions of OCB have been identified over time but there is huge overlapping in these terms. Podsakoff et al. (2000) have classified these into seven common dimensions: (1) Helping Behavior, (2) Sportsmanship, (3) Organizational Loyalty, (4) Organizational Compliance, (5) Individual Initiative, (6) Civic Virtue, and (7) Self Development.

It is very important to study the factors which effect the performance evaluation because this evaluation is subsequently used for many important decisions in the organization including promotion and transfer decisions (Cocanougher \& Ivancevich, 1978), identifying the training programs (Churchill et al. 1976; Dubinsky \& Staples, 1981) and compensation (Chonko, 1986; Ilgen \& Feldman, 1983). Early studies of performance evaluation (Behrman \& Perreault, 1982; Heneman, 1986; Weitz, 1978) have shown very small percentage (6\% to 9\%) variance in subjective performance evaluations due to the objective measures of performance. Podsakoff, MacKenzie, and Hui (1993) have indicated that there are certain behaviors, which can not be measured using the objective criterion, known as extra-role behaviors taken into consideration in performance evaluations. Organ $(1988,1990,1997)$ has continuously emphasized that one such behavior may be OCB.

"Schema triggered affect" (Fiske \& Pavelchak, 1986) explains the underlying reason of this relationship. Usually managers try to identify the 'good employee' and the 'bad employee' while evaluating the performance. If the employee engages in $\mathrm{OCB}$, there are fair chances that he/she will be labeled as 'good employee' leading to positive affect and hence resulting in positive performance evaluation. Similarly, the Performance evaluator 
always look for distinctive information (DeNisi, Cafferty, \& Meglino, 1984) and as OCB is taken as distinct behavior, it is quite obvious that such behavior will be given some consideration in evaluation.

Another probable reason could be Reciprocity of Supervisor. When an experienced employee provides assistance to a less experienced coworker with a work-related problem (example of OCB) that the supervisor would have to deal with otherwise, the supervisor may reciprocate with a more favorable rating of the experienced employee's performance.

Many studies (Borman \& Motowidlo, 1997; MacKenzie, Podsakoff, \& Fetter, 1991; Motowidlo \& Van Scotter, 1994; Orr, Sackett, \& Mercer, 1989; Parks \& Sims, 1989; Podsakoff \& MacKenzie, 1994; Podsakoff, MacKenzie, $\&$ Hui, 1993; Werner, 1994) have empirically proved the fact that significant variance in overall subjective performance evaluations can be attributed to OCB. Podsakoff et al. (2000) narrated the number studies in which significant effect on performance evaluation was observed by each dimension. Altruism/Helping was proved to effect OCB in 8 studies out of 10 studies, Courtesy impact on OCB was proven in 1 study out of 6 , Sportsmanship effect was observed in 5 studies out of 8, Conscientiousness was proved to effect Performance rating in all the 3 studies while the Composite OCB Measure-Performance Evaluation relationship was proved in the only 1 study undertaken till now. Thus with possible exception of courtesy, each of citizenship behavior had a significant effect on performance evaluations in the majority of the studies in which it was included. Werner (1994) and Whiting, Podsakoff, and Pierce (2008) studies are very important as these confirmed positive causal relationship between OCB and Performance Evaluations.

OCB is not only considered in performance evaluations but also contributes more variance in performance evaluations than the objective performance. A meta-analysis by Podsakoff et al. (2000), in which 11 sample studies were included, showed that, on average, objective performance contributed $9.5 \%$ only whereas $42.9 \%$ was contributed by OCB and these both contributed $61.2 \%$ in overall performance evaluations. Barksdale and Werner's (2001) recent study adds to this emerging literature by proving that higher Altruism of employee leads to higher performance rating.

In addition to the studies done in developed countries like USA, there are some studies of Asian cultures. MoideenKutty et al. (2005) examined this relationship pharmaceutical company of India and found that objective performance contributes $9 \%$ variation in subjective performance evaluation, while $32 \%$ variation was explained by only OCB. But only two dimensions of OCB namely Sportsmanship and Civic Virtue were measured in the study. Similarly, Krilowicz \& Lowery (1996) deduced that supervisory evaluations were found to be determined as much by OCB as by objective performance for Dominican and American workers.

Based on the literature available, the current study examines whether Performance Evaluation is affected by Altruism, Courtesy, Sportsmanship, Conscientiousness, Civic Virtue, and OCB-Composite.

\subsection{OCB and Other Rewards}

OCB is expected to impact rewards. One particularly likely explanation of this effects is the norm of reciprocity (Gouldner, 1960). This means that as the OCB is beneficial to the manager and the organization, the employee is reciprocated by both beneficiaries. In support of this fact Blau (1964) and Homans (1961) have noted that people try to reciprocate a favor to those who have helped them, done them a favor, or treated them fairly. Therefore, when a subordinate performs citizenship behaviors (e.g., by helping a coworker who has fallen behind in his or her work or who has been absent from work because of an illness) that free up the supervisor's time to work on more important matters, one would expect that the organization would tend to reciprocate this help by compensating with good rewards. Also from a social exchange perspective, organization may feel a sense of obligation to the employee in response to the behavior shown which is valuable by the organization i.e OCB. Thus the organization wants to reward the employee in return of OCB in order to maintain equitable social exchange with the employee (Wayne, Bommer, \& Tetrick, 2002).

These premises have been proved in the OCB literature. For example, two studies by Mel and Michael (1997) were conducted, the results of which suggested that employees perceive a link between rewards and organizational reward practices and OCB. Deluga (1998) proved that employees who perform only the prescribed job and do not engage themselves in OCB receive fewer rewards. Similarly Dulebohn et al. (2005) proved that employees who display more OCB receive higher rewards than those who don't exhibit such behavior. For salary and/or reward recommendation Parks and Sims (1989), Allen and Rush (1998), and Kiker and Motowidlo (1999) have proved that OCB had significant effect on these decisions. Parks \& Sims (1989), Orr, Sacket, \& Mercer (1989) also gathered evidence to support that promotion recommendations are significantly related with OCB. Still there is a wide gap in the research that studies have not been done for analyzing the impact of $\mathrm{OCB}$ on Rewards. Impact of $\mathrm{OCB}$ on number of rewards including promotions, training, 
compensation (Podsakoff et al., 2000) pay raise decisions, performance ratings, material resources given to employees." (Dulebohn et al., 2005) and Salary Increment (Allen, 2006). Whiting, Podsakoff, \& Pierce (2008) directed that Researchers should pay additional attention to impact of OCB on pay allocation and promotions decisions in organizations... future research should include outcomes of managerial evaluations of employee performance, such as reward allocation and promotion decisions...Additional research will be needed to see if our findings can be replicated in other contexts.

Hence the current study is undertaken to analyze that whether rewards including Increment in salary and promotion are affected by Altruism, Courtesy, Sportsmanship, Conscientiousness, Civic Virtue, and OCB-Composite.

\section{Research Design and Methodology}

\subsection{Sample}

As emphasized by Stamper and Van Dyne (2003), the employees in service industry are the key players in achieving customer satisfaction, retention, and organizational performance. Banking industry, being a key service sector of Pakistan, has been selected for the study. The studies of OCB drawing sample from the banks include Ann et al. (1983); Hui, Lam, and Law, (2000); Williams, Pitre, and Zainuba, (2002) etc. It is a vibrant and remarkably growing sector of the Pakistan economy. Therefore, a random sample set of employees of different commercial banks were selected where two groups of employees participated in the study. One group was the sample and the other group served as the raters of sample employees' OCB. For each sample employee two colleagues/peers were selected as raters. 800 employees were selected to fill out the questionnaire containing OCB scale, and rewards information. For each sample employee two peers were selected for evaluation of OCB shown by sample employee. This means that for those 800 sample employees 1600 peers were selected and were given 1600 questionnaires. Out of those 800 questionnaires, 530 were returned yielding a response rate of $66.25 \%$. This process of collecting behavioral responses from three different sources involved risk in terms of comprehensive data set collection (Wagner \& Rush, 2000). For each sample employee questionnaire peer evaluation questionnaires were matched and 405 questionnaires had their complete set of peer evaluations yielding final response rate of $50.62 \%$. Various questionnaires with inconsistent and missing data were eliminated and finally responses of 360 sample employees and 720 raters were used for the analysis.

$31.7 \%$ of sample employees have not received any promotion throughout their tenure in the current bank while $27.2 \%, 25.8 \%, 9.2 \%, 3.3 \%$ and $2.5 \%$ have received $1,2,3,4$ and 5 promotions respectively.

Out of the 360 employees $64.1 \%$ have not received promotion and $35.9 \%$ have been promoted in the current working year.

$37.7 \%$ have received $50 \%$ or less, $17.7 \%$ have received $51 \%-100 \%, 11.4 \%$ have received $101 \%-200 \%$, $5.1 \%$ have received $201 \%-300 \%, 4.5 \%$ have received $301 \%-400 \%, 3.6 \%$ have received $401 \%-500 \%$, 3\% have received $501 \%-600 \%$ and $17.1 \%$ have received $601 \%$ or more Total Salary Increment for the entire Tenure.

$15.2 \%$ have received $5 \%$ or less, $46 \%$ have received $6 \%-15 \%, 19.4 \%$ have received $16 \%-25 \%$, $11 \%$ have received $26 \%-35 \%$, and $4.2 \%$ have received $36 \%-45 \%$ and $46 \%$ or more Salary Increment in the current working year.

47.7\% have attained A grade, $40.8 \%$ have attained B grade, 10.9\% have attained C grade and .6\% have attained D grade for the performance they have shown in the current year.

\subsection{Measures}

\subsubsection{Organizational Citizenship Behavior}

In order to measure the construct in full detail OCB was measured using the 32-item scale developed by Konovsky \& Organ (1996). Permission for the use of scale was taken from the authors. The items reflect the five dimensions of OCB proposed by Organ (1988)-Altruism, Courtesy, Sportsmanship, Conscientiousness, and Civic Virtue.

- Altruism mean that employee help others with organizationally relevant tasks (e.g. voluntarily helping less skilled or new employee).

- Courtesy means preventing problems deriving from the work relationship (e.g. encouraging discouraged co-workers for professional development).

- Sportsmanship implies that employees have a positive attitude and are willing to tolerate less than ideal circumstances without complaining. 
- Civic virtue means that employees responsibly participate in, and are concerned about, the welfare of the company (e.g. attending non-required meetings, giving creative suggestions for improvements).

- Conscientiousness is dedication to the job and desire to exceed formal requirements in aspects such as, punctuality or conservation of resources (e.g. working long days or keeping the organization's rules). (Organ, 1988).

The five dimensions have been most widely acknowledged and used in research (LePine, Erez, \& Johnson, 2002; Also see Gonzallez \& Grazo, 2006 for detailed references). Each dimension was measured with 7, 13, 5, 4, 3 items respectively. For each OCB item, the responses were rated on a seven-point Likert scale (1=Strongly Disagree to $7=$ Strongly Agree). Authors reported the reliabilities of 0.90, 0.87, 0.88, 0.84 and 0.80 for each dimension respectively. In the current study the items were slightly modified to fit the present setting (e.g., "I stay informed about developments in the company" was changed to "I stay informed about developments in the bank"). The Cronbach Alpha was calculated for each dimension which was 0.912, 0.945, 0.897, 0.844, and 0.835, and 0.953 respectively for each dimension and Composite measure of OCB. As self and peers, both ratings were taken, the single score for each item was reached by averaging the self and peer ratings for every sample (Wagner \& Rush, 2000)

\subsubsection{Organizational Rewards}

Three organizational rewards measured are as follows:

- Promotion: Promotion was measured through

○ Total Promotions: Total number of promotion received by the employee for the tenure served.

- Current Promotion: It was dummy coded as $0=$ Not promoted in the current year and $1=$ Promotion received in the current year

- Salary Increment: Salary increment was measured as

- Total Salary Increments: Measured in terms of Total Percentage increment in salary for the tenure served.

- Current Salary Increment: Measured in terms of Percentage salary increment received in the current year.

- Performance Evaluation Grade: Performance evaluation was taken as the grade awarded to the employee in organization's annual performance report. The grades given in the banks are A, B, C, D. It was nominally coded as $\mathrm{A}=4, \mathrm{~B}=3, \mathrm{C}=2, \mathrm{D}=1$.

\subsection{Analysis Techniques}

Correlation analysis was done to ascertain the relationship of OCB with the rewards and t-test was used for the significant difference in the display of OCB by the promoted and not promoted employees. General Linear Model Multivariate Analysis was performed to investigate the impact of OCB on rewards received by employee.

\section{Analysis and Interpretations}

Following the discussed methodology, the data was collected from banking sector employees and analyzed for testing the OCB-Rewards relationship using Correlation, t-test and General Linear Multivariate Method. The reward variables taken in the study are Total Promotion, Promotion, Total Salary Increment, Current Salary Increment and Annual Performance grade. Altruism, Courtesy, Sportsmanship, Conscientiousness, and Civic Virtue dimensions are taken to measure OCB. This section is divided into two sub sections:

- Association of OCB and Rewards

- Rewards as consequences of OCB

\subsection{Association of $O C B$ and Rewards}

Association of OCB and Rewards is analyzed using correlation analysis, the results are summarized in the Table on page: 8. Altruism is positively related to all the rewards included but significant positive correlation is proved for Total Promotion $(r=0.110, p<0.05)$, Total Salary Increment $(r=0.115, \mathrm{p}<0.05)$, and Current Salary Increment $(\mathrm{r}=0.134, \mathrm{p}<0.05)$. Courtesy is proved to be positively related to all the rewards except Current Salary Increment. The required significance level is achieved for Total Promotion $(\mathrm{r}=0.092, \mathrm{p}<0.10)$, and Total Salary Increment $(\mathrm{r}=0.097, \mathrm{p}<0.10)$. Sportsmanship is also positively related to all the rewards except Current Salary Increment. This relationship is proved to be significant for Annual Performance Grade $(r=0.091, p<0.10)$. Conscientiousness is positively significantly related to Total Promotion ( $r=0.0116, p<0.05)$, Promotion $(r=0.106, p<0.05)$, and 
Annual Performance Grade $(\mathrm{r}=0.097, \mathrm{p}<0.10)$. Civic Virtue is positively related to all the rewards. Positive significant correlation is proved with Total Promotion $(\mathrm{r}=0.166, \mathrm{p}<0.01)$, and Annual Performance Grade $(\mathrm{r}=0.097, \mathrm{p}<0.10)$. As expected the Composite Measure of OCB is proved to be positively related to Total Promotion, Promotion, Total Salary Increment, Current Salary Increment and Annual performance Grade. Significant Positive Correlation is proved with Total Promotion $(r=0.111, p<0.05)$ and Total Salary Increment $(\mathrm{r}=0.111, \mathrm{p}<0.05)$.

Table 1. Correlation of rewards and OCB

\begin{tabular}{|c|c|c|c|c|c|c|c|c|c|c|c|c|}
\hline & & 1 & 2 & 3 & 4 & 5 & 6 & 7 & 8 & 9 & 10 & 11 \\
\hline 1 & Total Promotions & & & & & & & & & & & \\
\hline 2 & Promotions & $0.346 * * *$ & & & & & & & & & & \\
\hline 3 & Total Salary Increments & $0.547 * * *$ & 0.000 & & & & & & & & & \\
\hline 4 & Current Salary Increment & 0.076 & $0.143 * * *$ & $0.115^{* *}$ & & & & & & & & \\
\hline 5 & Annual Performance Grade & $0.141 * *$ & $0.117^{* *}$ & -0.032 & 0.077 & & & & & & & \\
\hline 6 & Altruism & $0.110^{* *}$ & 0.037 & $0.115^{* *}$ & $0.134 * *$ & 0.063 & & & & & & \\
\hline 7 & Courtesy & $0.092 *$ & 0.050 & $0.097 *$ & -0.016 & 0.052 & $0.794 * * *$ & & & & & \\
\hline 8 & Sportsmanship & 0.013 & 0.039 & 0.063 & -0.079 & $0.091 *$ & $0.169 * * *$ & $0.298 * * *$ & & & & \\
\hline 9 & Conscientiousness & $0.125 * *$ & 0.033 & $0.116 * *$ & -0.024 & 0.054 & $0.626 * * *$ & $0.773 * * *$ & $0.219 * * *$ & & & \\
\hline 10 & Civic Virtue & $0.166 * * *$ & $0.106 * *$ & 0.040 & 0.060 & $0.097 *$ & $0.633^{* * *}$ & $0.736 * * *$ & $0.118 * *$ & $0.693 * * *$ & & \\
\hline 11 & OCB & $0.111 * *$ & 0.060 & $0.111 * *$ & 0.010 & 0.086 & $0.836 * * *$ & $0.943 * * *$ & $0.507 * * *$ & $0.806 * * *$ & $0.754 * * *$ & \\
\hline
\end{tabular}

To check whether the people who are promoted show significant different level of OCB than the people who are not promoted, Independent Sample t-test was run. The results are summarized in the table below

Table 2. T-test of promotion and OCB

\begin{tabular}{lllll}
\hline & Promotion & Mean & S.D & T \\
\hline Altruism & No & 5.41 & .764 & 0.721 \\
Courtesy & Yes & 5.47 & .718 & 0.971 \\
& No & 5.55 & .726 & 0.738 \\
Sportsmanship & Yes & 5.62 & .660 & \\
No & Yes & 4.07 & 1.125 & 0.627 \\
Civic Virtue & No & 4.16 & 1.16 & \\
& Yes & 5.55 & .801 & $2.098^{*}$ \\
OCB- Composite & No & 5.60 & .769 & .883 \\
& Yes & 5.42 & .762 & 1.159 \\
\hline
\end{tabular}

Note. ${ }^{*} \mathrm{p} \leq 0.05$.

The results show that people who show different level of Civic Virtue are promoted in the current year than the people who are not promoted. This difference is proved to be significant. Mean of all the dimensions and OCB-Composite is higher for the people who are promoted than those of the people who are not promoted. Significant difference is proved only for Civic Virtue. For all other dimensions of OCB and OCB-Composite, no significant difference was proved. This result highlights the fact that employees who are promoted take macro-level interest commitment 


\subsection{Rewards as Consequences of $O C B$}

The next step is to analyze the impact of OCB on rewards. According to the hypotheses OCB is supposed to have significant impact on the rewards employee receives. For the said purpose, General Linear Model Multivariate Analysis was chosen as impact of each OCB dimension on multiple rewards variable needs to be scrutinized. All individual dimensions of OCB including Altruism, Courtesy, Sportsmanship, Conscientiousness and Civic Virtue as well as OCB-Composite were taken as independent variables whereas all the rewards variables including Total Promotion, Promotion, Total Salary Increment, Current Salary Increment and Annual Performance Ratings were taken as dependent variables. Each dimension individually and OCB-Composite was regressed for the rewards variables.

The first dimension, Altruism, was taken as independent variable and the rewards which proved to be significantly correlated to it are taken as dependent variable in the first model. The results are summarized in the following table.

Table 3. GLMM of altruism and rewards

\begin{tabular}{|c|c|c|c|c|}
\hline Independent & Dependent & & & \\
\hline \multirow{3}{*}{ ALTRUISM } & Total Promotion & $0.002 * *$ & & \\
\hline & Total Salary Increment & & $0.018^{* * *}$ & \\
\hline & Current Salary Increment & & & $0.022 * * *$ \\
\hline
\end{tabular}

Note. ***Significant at the 0.01 level; **Significant at the 0.05 level.

Altruism predicts the Total Salary Increment and Current Salary Increment. Though significantly correlated to Total Promotion, Altruism is not proved to be significant predictor of it. The relationship of Altruism, Total Salary Increment and Current Salary Increment is proved to be significant. Thus Altruism predicts the Salary increment an employee receives for the current year as well as for the entire period of service in the bank.

The next tested model is for the Courtesy dimension of OCB. Total Promotion and Total Salary increment were proved to be significantly correlated to Courtesy and hence have been included in the model as dependent variables. The results are displayed in the Table 4.

Table 4. GLMM of courtesy and rewards

\begin{tabular}{|c|c|c|c|}
\hline Independent & Dependent & & \\
\hline \multirow{2}{*}{ COURTESY } & Total Promotion & $0.009 *$ & \multirow{2}{*}{$0.009^{*}$} \\
\hline & Total Salary Increment & & \\
\hline
\end{tabular}

Note. *Significant at the 0.10 level.

Courtesy predicts Total Promotion and Total salary Increment which means the number of promotions and percentage salary increment employee receives throughout the period of service in the bank is significantly dependent on the level of Courtesy shown.

In the next model Sportsmanship is regressed for all the rewards variables. Following results were attained:

Table 5. GLMM of sportsmanship and rewards

\begin{tabular}{cll}
\hline Independent & Dependent & \\
\hline \multirow{2}{*}{ SPORTSMANSHIP } & Total Promotion & 0.001 \\
& Promotion & 0.002 \\
& Total Salary Increment & 0.002 \\
& Current Salary Increment & $0.013^{* *}$ \\
& APG & 0.004 \\
\hline
\end{tabular}


The Current Salary Increment is significantly dependent on the Sportsmanship whereas other rewards variables are not proved to be significantly effected by the level of Sportsmanship. Fourth model is formulated taking Conscientiousness as independent variable and Total Promotion and Total Salary Increment as dependent variables. Results of the model are displayed in the following Table.

Table 6. GLMM of conscientiousness and rewards

\begin{tabular}{clll}
\hline \multicolumn{1}{c}{ Independent } & Dependent & & \\
\hline CONSCIENTIOUSNESS & Total Promotion & $0.015^{* *}$ & $0.011^{* *}$ \\
& Total Salary Increment & & $0.013^{* *}$ \\
\hline
\end{tabular}

Note. $* *$ Significant at the 0.05 level.

Conscientiousness predicts Total Promotion and Total Salary Increment which means the number of promotions and percentage salary increment employee receives throughout the period of service in the bank is significantly dependent on the level of Conscientiousness shown.

Next model tested is for Civic Virtue dimension. Total Promotion, Promotion and Annual Performance Rating are significantly correlated with Civic Virtue therefore have been included in the model as dependent variables. Results of the model are presented in the following Table.

Table 7. GLMM of civic virtue and rewards

\begin{tabular}{clcc}
\hline Independent & Dependent & & \\
\hline \multirow{3}{*}{ Civic Virtue } & Total Promotion & $0.018^{* *}$ & $0.005^{* *}$ \\
& Promotion & 0.007 & $0.009^{*}$ \\
& Annual Performance Rating & & \\
\hline
\end{tabular}

Note. ***Significant at the 0.01 level; **Significant at the 0.05 level.

Results show that Total Promotion and Annual Performance Rating are significantly dependent on the Civic Virtue.

OCB-Composite was regressed for the significantly correlated rewards variables, results are shown in the Table below.

Table 8. GLMM of OCB and rewards

\begin{tabular}{cll}
\cline { 2 - 3 } Independent & Dependent & \\
\cline { 2 - 3 } OCB-Composite & Total Promotion & $0.013^{* *}$ \\
& Total Salary Increment & $0.012^{* *}$ \\
\hline
\end{tabular}

Note. **Significant at the 0.05 level.

OCB-Composite is proved to be significant predictor of Total Promotion and Total Salary Increment. It indicates that the number of promotions and percentage salary increment employee receives throughout the period of service in the bank is significantly dependent on the level of OCB shown.

\section{Conclusion}

The purpose of this research was to test relationship of possible variables (Total Promotion, Promotion, Total Salary Increment, Current Salary Increment, and Annual Performance Grade) with OCB in the service sector context. We explored these factors in the context of Pakistan in order to fill the gap and contribute to the emerging theoretical explanation of OCB. Study results indicate that OCB is related to the rewards. Altruism, Courtesy, Conscientiousness and Civic Virtue dimensions OCB-Composite are related to Total Promotions an employee has received from the organization. Promotion is related to Civic Virtue dimension. The people who 
are promoted display higher level of Civic Virtue than those who have not been promoted. Altruism, Courtesy and Conscientiousness as well as OCB-Composite are related to Total Salary Increments an employee receives. Altruism is related to Current Salary Increment. Sportsmanship and Civic Virtue are related to the Annual Performance Grade the employee receives. All these relationships of OCB and rewards are proven to be significant and positive. Altruism is positively significantly related to the maximum number of rewards proving that higher Altruism leads to more and higher rewards because Altruism is valued much more than any other OCB dimension. This means that the employees who frequently help other coworkers in work-related problems receive more and higher rewards than those who help less frequently.

General Linear Multivariate Method (GLMM) results confirm to our expectations that OCB impact the rewards received by employee. Altruism impacts Total Salary Increments and Current Salary Increment positively. The employees, who frequently lend a helping hand to the co-workers, receive higher salary increments than those who help less frequently. Courtesy and Conscientiousness positively predicts Total Promotions and Total Salary Increments The employees, who prevent problems arising from work relationships and those who adhere to the rules and regulations of the organization climb up the rank ladder faster and get higher salary increments for the period of service in the organization. Sportsmanship predicts Current Salary Increment positively implying that employees who tolerate inconveniences without complaining receive more pay raise than those who often complain. Civic Virtue positively predicts Total Promotions and Annual Performance Grade indicating that employees who take active interest in the life of the organization receive more promotions and better performance grade than other employees. This finding is in line with the findings of Indian study by MoideenKutty et al. (2005). OCB-Composite is positive predictor of Total Promotions and Total Salary Increments proving that employees displaying higher level of OCB receive more promotions and higher salary increments throughout their period of service in the organization. At least two rewards are proven to be consequences of OCB-Composite as well as all o its dimensions except Sportsmanship indicating considerable impact of OCB on rewards.

Our findings are important because they suggest that managers consider Civic virtue to be an important part of an employee's overall contribution to the organization and that is why rate those employees higher on the performance evaluation as compared to others. Hence employees who want good performance rating need to perform not only the job prescribed behavior but also need to take interest in the life of the organization by attending non required meetings, taking initiatives for improvements, and welcoming change in the organization etc. Knowing that employees are evaluated on their OCB, it is important to know that they consider it to be air. Johnson et al. (2009) proved that evaluating employees on OCB was taken as fair by employees. OCB weightings of 30-50\% were perceived as the most fair. Another interesting result is that Sportsmanship is proved to impact Current Salary Increment. This implies that employees' tolerance of inconveniences and no complain attitude is immediately rewarded by giving more salary increment. This may be because no complain attitude is taken as indication of satisfaction and commitment to the company. Sportsmanship is not proved to impact other rewards as it is less visible form of OCB than others.

A closer look into the results of the study reveals that the OCB does not impact rewards in the short term only but also in the long-term as among others Total Promotion and Total Salary Increment has been found to be significant consequences of OCB. Total Promotions and Total Salary Increment is proved to be consequence of maximum number of OCB dimensions as well as of Composite Measure of OCB. This implies that the display of OCB leads to more promotions and higher salary increments for the employee for the period of service in the organization. Hence even if the employee does not immediately receive any reward in the result of OCB, he can expect rewards over the long run. This may have been because of the fact that immediate dissemination of rewards is not always possible for the organization, due to numerous reasons, even if it intends to reward employee for the display of OCB. As Podsakoff et al. (2009) found relatively stronger, positive relationship of OCB with reward allocation decisions than actual rewards implying that OCBs have a substantial impact on reward recommendations which may not always translate into the actual administration of rewards.

OCB dimensions and OCB-Composite either have no effect on some of the rewards or have positive effects on the other rewards. OCB does not negatively affect any of the reward in any case. Thus employees must show higher OCB in order to receive higher rewards. All employees should know that their rewards are positively affected by OCB and be careful about their behavior. The employees should be rewarded according to their performance whether job related or OCB and merit pay plans should be discouraged because they restrain the display of many of citizenship behaviors. 


\section{References}

Adams, J. S. (1965). Inequity in social change. In L. Berkowitz (Ed.), Advances in Experimental Social Psychology (Vol. 83, pp. 247-260).

Allen, T. D. (2006). Rewarding good citizens: The relationship between citizenship behavior, gender, and organizational rewards. Journal of Applied Social Psychology, 36(1), 120-143. http://dx.doi.org/10.1111/j.0021-9029.2006.00006.x

Allen, T. D., \& Rush, M. C. (1998). The effects of organizational citizenship behavior on performance judgments: A field study and a laboratory experiment. Journal of Applied Psychology, 83, 247-260. http://dx.doi.org/10.1037/0021-9010.83.2.247

Allen, T. D., Barnard, S. M., Rush, M. C., \& Russell, J. E. A. (2000). Ratings of organizational citizenship behavior: Does the source make a difference? Human Resource Management Review, 10, 97-114. http://dx.doi.org/10.1016/S1053-4822(99)00041-8

Alotaibi, A. G. (2001). Antecedents of organizational citizenship behavior: A study of public personnel in Kuwait. Public Personnel Management, 30(3), 363-376.

Ann, S. C., Organ, D. W., \& Near, J. P. (1983). Organizational citizenship behavior: Its nature and antecedents. Journal of Applied Psychology, 68(4), 653-663. http://dx.doi.org/10.1037/0021-9010.68.4.653

Barksdale, K., \& Werner, J. M. (2001). Managerial ratings of in-role behaviors, organizational citizenship behaviors, and overall performance: Testing different models of their relationship. Journal of Business Research, 51, 145-155. http://dx.doi.org/10.1016/S0148-2963(99)00061-2

Barnard, C. (1938). The functions of the executive thirtieth anniversary edition (1968). Cambridge, M. A: Harvard University Press.

Becker, T. E., \& Vance, R. J. (1993). Construct validity of three types of organizational citizenship behavior: An illustration of the direct product model with refinements. Journal of Management, 19, 663-682. http://dx.doi.org/10.1177/014920639301900309

Behrman, D. N., \& Perrault, W. D. (1982). Measuring the performance of industrial salespeople. Journal of Business Research, 10, 355-370. http://dx.doi.org/10.1016/0148-2963(82)90039-X

Bettencourt, L. (1998). The service-oriented citizenship performance of customer-contact employees. UMI dissertation services. Arizona State University.

Blau, P. M. (1964). Exchange and power in social life. New York: Wiley Publications.

Borman, W. C., \& Motowidlo, S. J. (1997). Task performance and contextual performance: The meaning for $\begin{array}{lllll}\text { personnel selection } & \text { research. Human Performance, } & 10, & \text { 99-109. }\end{array}$ http://dx.doi.org/10.1207/s15327043hup1002_3

Chonko, L. B. (1986). Organizational commitment in the salesforce. Journal of Personal Selling and Sales Management, 6, 19-27.

Churchill, Jr. G. A., Neil, M. F., \& Orville, C. W. Jr. (1976). Organizational climate and job satisfaction in the salesforce. Journal of Marketing Research, 13(4), 323-332. http://dx.doi.org/10.2307/3151014

Cocanougher, B. A., \& Ivanoevich, J. M. (1978). Bare' Performance Rating for Sales Force Personnel. Journal of Marketing, 42, 87-95. http://dx.doi.org/10.2307/1250540

Deluga, R. J. (1995). The relation between trust in the supervisor and subordinate organizational citizenship behavior. Military Psychology, 7, 1-16. http://dx.doi.org/10.1207/s15327876mp0701_1

DeNisi, A. S., Cafferty, T. P., \& Meglino, B. M. (1984). A cognitive view of the performance appraisal process: A model and research propositions. Organizational Behavior and Human Performance, 33, 360-396. http://dx.doi.org/10.1016/0030-5073(84)90029-1

Dubinsky, A. J., \& William A. S. (1981). Are industrial salespeople buyer oriented? Journal of Purchasing and Materials Management, 17, 12-19.

Dulebohn, J. H., Shore, L. M., Kunze, M., \& Dookeran, D. (2005). The differential impact of OCBs and influence tactics on leader reward behavior and performance ratings over time. Organizational Analysis, 13(1), 73-90.

Farh, J. L., Earley, P. C., \& Lin, S. C. (1997). Impetus for action: A cultural analysis of justice and organizational 
citizenship behavior in Chinese society. Administrative Science Quarterly, 42(3), 421-444. http://dx.doi.org/10.2307/2393733

Farh, J. L., Zang, C. B., \& Organ, D. W. (2004). Organizational citizenship behavior in the People's Republic of China. Organization Science, 15(2), 241-253. http://dx.doi.org/10.1287/orsc.1030.0051

Fiske, S. T., \& Pavelchak, M. (1986). Category-based versus Piecemeal-based affective responses: Developments in Schema-triggered affect. In R. M. Sorrentino \& E. T. Higgens (Eds.), The Handbook of Motivation and Cognition: Foundations of Social Behavior (pp. 167-203). Guilford: New York.

George, J. M., \& Bettenhausen, K. (1990). Understanding prosocial behavior, sales performance, and turnover: A Group-level analysis in a service context. Journal of Applied Psychology, 75, 698-709. http://dx.doi.org/10.1037/0021-9010.75.6.698

Gonzalez, J. V., \& Garazo, T. G. (2006). Structural relationships between organizational service orientation, contact employee job satisfaction and citizenship behavior. International Journal of Service Industry Management, 17(1), 23-50. http://dx.doi.org/10.1108/09564230610651561

Gouldner, A. W. (1960). The norm of reciprocity: A preliminary statement. American Sociological Review, 25, 161-178. http://dx.doi.org/10.2307/2092623

Heneman, R. L. (1986). The relationship between supervisory ratings and results oriented measures of $\begin{array}{llll}\text { performance: A } & \text { meta-analysis. Personnel Psychology, }\end{array}$ http://dx.doi.org/10.1111/j.1744-6570.1986.tb00596.x

Homans, G. (1961). Social behavior: It's elementary forms. New York: Harcourt Brace.

Huang, J. H., Jin, B. H., \& Yang, C. (2003). Satisfaction with business-to-employee benefit system and organizational citizenship behavior: An examination of gender differences. International Journal of Manpower, 25, 196-210.

Hui, C., Lam, S. S. K., \& Law, K. K. S. (2000). Instrumental values of organizational citizenship behavior for promotion: A field quasi-experiment. Journal of Applied Psychology, 85(5), 822-828. http://dx.doi.org/10.1037/0021-9010.85.5.822

Ilgen, D. R., \& Feldman, J. M. (1983). Performance appraisal: A process focus. In B. Staw \& L. Cummings (Eds.), Research in organizational behaviour (Vol. 5). Greenwich, CT: JAI Press.

Johnson, S., Holladay, C., \& Quinones, M. (2009). Organizational citizenship behavior in performance evaluations: Distributive justice or injustice? Journal of Business \& Psychology, 24(4), 409-418. http://dx.doi.org/10.1007/s10869-009-9118-0

Kiker, D. S., \& Motowidlo, S. J. (1999). Main and interaction effects of task and contextual performance on supervisory reward decisions. Journal of Applied Psychology, 84, 602-609. http://dx.doi.org/10.1037/0021-9010.84.4.602

Konovsky, M. A., \& Organ, D. W. (1996). Dispositional and contextual determinants of organizational citizenship behavior. Journal of Organizational Behavior, 17(3), 253-266. http://dx.doi.org/10.1002/(SICI)1099-1379(199605)17:3<253::AID-JOB747>3.0.CO;2-Q

Krilowicz, T. J., \& Lowery, C. M. (1996). The impact of organizational citizenship behavior on the performance appraisal process: A cross cultural study. International Journal of Management, 13, 94-100.

Kuehn, K. W., \& Al-Busiadi, Y. (2002). Citizenship behavior in a non-western context: An examination of the role of satisfaction, commitment and job characteristics on self-reported OCB. International Journal of Conflict Management, 12(2), 107.

LePine, J. A., Erez, A., \& Johnson, D. E. (2002). The nature and dimensionality of OCB: A critical review and meta-analysis. Journal of Applied Psychology, 87, 52-65. http://dx.doi.org/10.1037/0021-9010.87.1.52

Mackenzie, S. B., Podsakoff, P. M., \& Fetter, R. (1991). Organizational citizenship behavior and objective productivity as determinants of managerial evaluations of salesperson performance. Organizational Behavior and Human Decision Processes, 50, 123. http://dx.doi.org/10.1016/0749-5978(91)90037-T

Mel, S., \& Michael, P. D. (1997). Organizational citizenship behavior: The impact of rewards and reward practices. Journal of Managerial Issues, 9(2), 216-229.

Milkovick, G. T., \& Newman, J. M. (1996). Compensation (5th ed.). Chicago: Irwin Publications.

Moideenkutti, U., Blau, G., Kumar, R., \& Nalakath, A. (2005). Relationship of organizational citizenship 
behavior and objective productivity to managerial evaluations of performance in India. International Journal of Commerce and Management, 15, 221-228. http://dx.doi.org/10.1108/10569210580000198

Moorman, R. H. (1991). Relationship between organizational justice and organizational citizenship behaviors: Do fairness perceptions influence employee citizenship? Journal of Applied Psychology, 76, 845-855. http://dx.doi.org/10.1037/0021-9010.76.6.845

Motowidlo, S. J., \& Van Scotter, J. R. (1994). Evidence that task performance should be distinguished from contextual performance. Journal of Applied Psychology, 79, 475-480. http://dx.doi.org/10.1037/0021-9010.79.4.475

Organ, D. W. (1988). Organizational citizenship behavior: The good soldier syndrome. Lexington, M.A: Lexington Books.

Organ, D. W. (1990a). The motivational basis of organizational citizenship behavior. Research in Organizational Behavior, 12, 43-72.

Organ, D. W. (1990b). The subtle significance of job satisfaction. Clinical Laboratory Management Review, 4, 94-98.

Orr, J. M., Sackett, P. R., \& Mercer, M. (1989). The role of prescribed and nonprescribed behaviors in estimating the dollar value of performance. Journal of Applied Psychology, 74, 34-40. http://dx.doi.org/10.1037/0021-9010.74.1.34

Park, O. S., \& Sims, H. P. Jr. (1989). Beyond cognition in leadership: Prosocial behavior and affect in managerial judgment. Working paper, Seoul National University and Pennsylvania State University.

Podsakoff, N. P., Whiting, S. W., Podsakoff, P. M., \& Blume, B. D. (2009). Individual- and organizational-level consequences of organizational citizenship behaviors: A meta-analysis. Journal of Applied Psychology, 94(1), 122-141. http://dx.doi.org/10.1037/a0013079

Podsakoff, P. M., \& Mackenzie, S. B. (1994). Organizational citizenship behavior and sales unit effectiveness. Journal of Marketing Research, 3(1), 351-363.

Podsakoff, P. M., Mackenzie, S. B., \& Hui, C. (1993). Organizational citizenship behaviors and managerial evaluations of employee performance: A review and suggestions for future research. In G. R. Ferris (Ed.), Research in personnel and human resources management (Vol. 11, pp. 1-40). Greenwich, CT: JAI Press.

Podsakoff, P. M., Mackenzie, S. B., Paine, J. B., \& Bachrach, D. G. (2000). Organizational citizenship behaviors: A critical review of the theoretical and empirical literature and suggestions for future research. Journal of Management, 26(3), 513-563. http://dx.doi.org/10.1177/014920630002600307

Schnake, M. E. (1991). Equity in effort: The "sucker effect" in co-acting groups". Journal of Management, 17, 41-55. http://dx.doi.org/10.1177/014920639101700104

Stamper, C. L., \& Van, D. (2003). Organizational citizenship: A comparison between part-time and full-time service employees. Cornell Hotel and Restaurant Administration Quarterly, 44, 33-42. http://dx.doi.org/10.1016/S0010-8804(03)90044-9

Sun S. B. (2001). Predicting job satisfaction and organizational citizenship behavior with individualism and collectivism in P.R. China and United States. Published dissertation, University of South Florida.

Van Dyne, L., \& Ang, S. (1996). Organizational citizenship behavior of contingent workers in Singapore. Academy of Management Journal, 41(6), 692-703. http://dx.doi.org/10.2307/256965

Wagner, S. L., \& Rush, M. C. (2000). Altruistic organizational citizenship behavior: Context, disposition, and age. The Journal of Social Psychology, 140(3), 379-391. http://dx.doi.org/10.1080/00224540009600478

Wanxian, L., \& Weiwu, W. (2006). A demographic study on citizenship behavior as in-role orientation. Personality and Individual Differences, 10, 1016.

Wayne, S. J., Shore, L. M., Bommer, W. H., \& Tetrick, L. E. (2002). The role of fair treatment and rewards in perceptions of organizational support and leader-member exchange. Journal of Applied Psychology, 87, 590-598. http://dx.doi.org/10.1037/0021-9010.87.3.590

Weitz, B. A. (1978). The relationship between salesperson performance and understanding of customer decision making. Journal of Marketing Research, 15, 501-516. http://dx.doi.org/10.2307/3150621

Werner, J. M. (1994). Dimensions that make a difference: Examining the impact of in-role and extra-role behaviors on supervisory ratings. Journal of Applied Psychology, 79(1), 98-107. 
http://dx.doi.org/10.1037/0021-9010.79.1.98

Whiting, S. W., Podsakoff, P. M., \& Pierce, J. R. (2008). Effects of task performance, helping, voice and organizational loyalty on performance appraisal ratings. Journal of Applied Psychology, 93(1), 125-139. http://dx.doi.org/10.1037/0021-9010.93.1.125

Williams, S., Pitre, R., \& Zainuba, M. (2002). Justice and organizational citizenship behavior intentions: Fair rewards versus fair treatment. The Journal of Social Psychology, 142(1), 33-44. http://dx.doi.org/10.1080/00224540209603883

\section{Copyrights}

Copyright for this article is retained by the author(s), with first publication rights granted to the journal.

This is an open-access article distributed under the terms and conditions of the Creative Commons Attribution license (http://creativecommons.org/licenses/by/3.0/). 